\title{
次世代ヒューマンロボットインタラクションデザイン研究の 展望と課題
}

Visions for the Next Generation Human Robot Interaction Design

中小路 久美代 $* 1 * 2 \quad * 1$ 京都大学学際融合教育研究推進センターデザイン学ユニット ${ }^{* 2}$ 株式会社 SRA 先端技術研究所 Kumiyo Nakakoji ${ }^{*} * 2$

${ }^{* 1}$ Unit of Design, Center for the Promotion of Interdisciplinary Education and Research, Kyoto University ${ }^{* 2}$ Key Technology Laboratory, Software Research Associates, Inc.

\section{1.は じめに}

私は, インタラクションデザインという分野において， ヒューマンコンピュータインタラクション $(\mathrm{HCI})$ という 分野におけるソフトウェアとそのデザインの研究を行って いる. 人間の知的創造作業（例えば文章執筆の初期段階や, 実験データの探索的分析）のための，ソフトウェアシステ ムの表現系と操作系のデザインをナレッジインタラクショ ンデザインと呼び, ツールやモデルの構築を行ってきた $[1]$.

人間が使用するコンピュータシステムを構築するという ときに，二つの世界を同時に構築することになると考えて いる [2]. 一方は, 構築するシステムの世界, もう一方は, 構築したシステムを利用する人間にとって出来上がる世界, である（図 1)。私はこれまで，前者を the world of making 〈作るモノの世界〉, 後者を the world of using〈使うコトの 世界〉と呼び，この二つは密接に連携しながらも別の世界 であり，これらを区別して作り上げる必要があると考えて きた，前者は，プログラムで表される世界であり数学的一 貫性に基づいて正しく実装され実行される必要がある。後 者には，人間がそのシステムとやりとり（インタラクショ ン）を行う際に, 人間から見たときの認知的な一貫性が求 められる，後者の造形は，システムの表現系と操作系がど うあるべきかという観点から，2000 年代の初頭以降はイン タラクションデザインと呼ばれている。

コンピュータシステムをロボットに置き換えても，まっ たく同じ構図が成立するように感じている，ここで「ロボッ 卜」という言葉は, 外部環境のコンテキストに応じて自律 的に物理的な様相（位置や姿勢，形状）を変化することの できる機構を指し示す名称として用いている.

主としてディスプレイ上の表示をインタラクションのメ

原稿受付 2014 年 9 月 24 日

キーワード: Human-robot Interaction Design, The World of Using, Socio-technical Systems, Design Visions

*1 个 606-8501 京都市下京区吉田本町

$* 2$ 厂 171-0022 豊島区南池袋 2-32-8

${ }^{* 1}$ Sakyo-ku, Kyoto-shi, Kyoto

${ }^{* 2}$ Toshima-ku, Tokyo

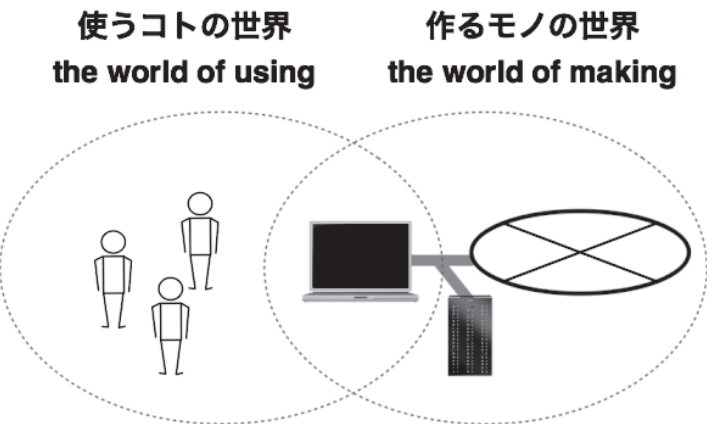

図 1 <作るモノの世界 > (右) と<使うコトの世界 > (左)

ディアとして想定しているソフトウェアシステムとは異な り，ロボット（注：上記の定義によるロボット）は，物理 的様相を伴う。間の身体のサイズに対して, 微小なもの から巨大なものまでがあり得る。人間の身体の中に入り込 むこともあれば，人間を包み込むこともあるであろう。

日本が先導するヒューマンロボットインタラクション （HRI）という研究分野がある。人間が，ロボットという 個体と，どのようにやりとり（インタラクション）をすべ きかを探求している研究分野であるように見受けられる。

本論では，人間の営為の一部にロボットが入り込んだり， 人間のアクションを包み込んだりするような位置づけのロ ボットを考え，そのコンテキストでの HRI デザインを展望 してみる。ロボットが個体として認識されないようなとこ ろである, 10 年後, 20 年後, あるいは 50 年後を見据えた 話である.

下記に示すスケッチは, 図 1 に示したところの, 〈使うコ トの世界〉の展望に相当するところである。このような左 側の世界を考える際に，作るモノの世界，すなわち技術的 課題として何を考えるべきか, ということの考えの一助と なれば幸いである。

\section{2. ロボットを〈使うコトの世界〉の展望}

\section{1 人間が造形するメディアとなるロボット}

人間は，創造的な創作活動において，紙とペンを使って スケッチしたり, ホワイトボードとマーカーを使ってディ 


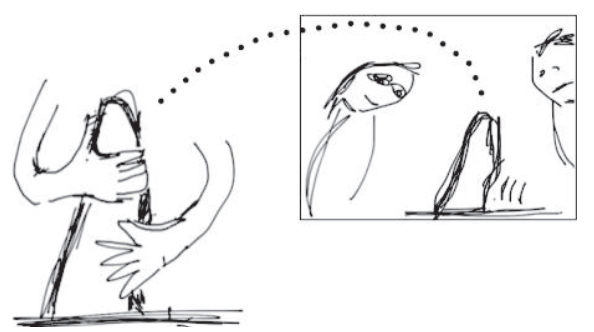

図 2 人間が造形するためのメディアとなるロボットのイメージ

スカッションしたり, 段ボールを使って low-fidelity なプ ロトタイプを使ったり，粘土を使って模型を作ったりする. デザインプロセスの，特に初期段階においては，人間がこ のように作り出すビジュアルな表現からの語りかけ（talkback）を聞き，表現と対話を行うことが重要であるとされ ている $[3] \sim[5]$.

こういったメディアがロボットになることを考える，例 えば粘土が, 微小なツブッブのロボットで構成されている とする，仮に粘土ロボットと呼ぶ.

粘土ロボットは，人間が作っていく過程を記憶する。こ うして，ああして，といった人間が作り出した形のプロセ スを逐一記録する，そのプロセスを，再現することができ る。離れたところにいるデザインプロジェクトのメンバー が使っている遠隔の粘土ロボットに，自分の今の形状をコ ピーすることができる. 人間が適当に平らにした表面や, 手 で作り出したカーブを, 数学的に美しい平面や曲面として スムーズにして整形 (rectify) する．作り出された形状の シーケンスを連続して再生することで，物体の動きのアニ メーションを作り出すことができる.

物体に対して行った操作の undoや，遠隔地にいる人に 対して，作り出しているモノの形状とその動きをそのまま 伝えられるようになる。画面上で手描きしたガタガ夕の線 を滑らかな線にしたり，また元のガタガ夕に戻したりといっ たことを，物理的な粘土が自動的にしてくれる．動きを伴 う物理的なモノのデザインのためのメディアとしては画期 的なメディアである。

粘土ロボットのポイントは, 机の上において, 人間が椅 子に座って素手で, 様々な形を作り出していけるくらいの 大きさである点である。痛かったり重たかったり熱かった り通電したりする危険性があると当然使えない，紙とペン や，土や，布と同様に，人間が自分の創作メディアとして 感じられるようになっている必要がある。 もちろん, 解像 度も重要である。

\section{2 机の上を片付けてくれるロボット}

机の上で活動できるロボットを考える，人間の多くの営 みは，「机の上」で行われる，食事が済んだ後の食卓の上の 片付けをしてくれる，大人が仕事をした後の散らかったデ スクを片付けてくれる, 子供が塗り絵をして遊んだ後を片

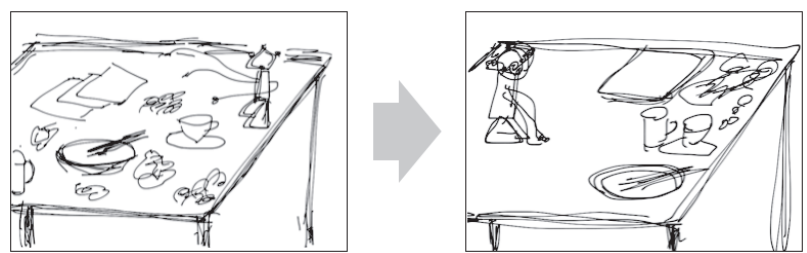

図 3 机の上を片付けてくれるロボットのイメージ

付けてくれる，といったことを物理的にしてくれるロボッ トを考える。

机の上にある様々な形状の物理的なものを，壊さず，か つ種類や用途ごとに, 重ねたり, 並べたりして, 片付ける. 人間がしばしば尋ねるであろう,「さっきここに置いた鍵は どこにいった？」といったことに対応できるように，片付 けたものは，時間を遡って元の場所に戻すこともできる.

机の上からさらに別の場所に移動するようなことは，別 のロボット（あるいは人間）に任せる，あくまで，机の上だ けが仕事場であるようなロボットを考える，机の上にずっ といるので，自分自身が大きいと邪魔になる，自分自身は こぢんまりしている必要がある，かつ，机の上の，狭かった り，べタベタだったり，平らな場所がなかったりする，その ような環境内を安定して移動できる必要がある，書類，食 べかす，腕時計，小銭，お皿といった，日々置かれる様々な ものを，人間にとって，一緒にしてはいけないもの，分け ておくべきもの，といった視点で識別する必要がある。物 理的にそれらをうまく把持したり移動できたり重ねたりす る必要がある。人型ロボットで, ちょっと跨いで移動した り, カップをちょっと動かして自分の移動場所を作り出す ようなロボットだと，かなり愛着がわく.

\section{3 身体内で人工組織となるロボット}

人工骨や人工関節といった，体内に組み入れる機構の一 部を，ロボットで作ることを考える，年齢を経るに従って 変化していく身体の機構に合わせて, 体内環境をセンシン グしつつ, 自律的にその物理特性を調整するようなロボッ トである、ロボットで作ることのポイントは，身体の他の 部分とのバランスをみつつ, その弾性や塑性を, 年齢に応 じた身体の変化に合わせて制御し変更できるようにすると ころにある。

人体に取り込まれて身体組織とインタラクションを行う ようなロボットである。人間が意思でインタラクションし たり制御したりするようなロボットではない。人体の原理, 身体内環境センシング，主体の外部環境のセンシング（家 の中を歩いている，石鼍を歩いている）といったことが必 要となるであろうことは明らかである，今から電車に飛び 乗ろうとしている，といった意図のセンシングが必要とな るかもしれない。

\section{4 即時適応性を有した建造物になるロボット}

階段や地面をロボットで作る。近づいて来た人のニーズ 


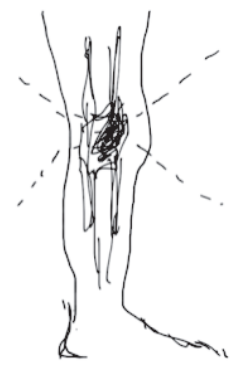

図 4 身体内で人工組織となるロボットのイメージ
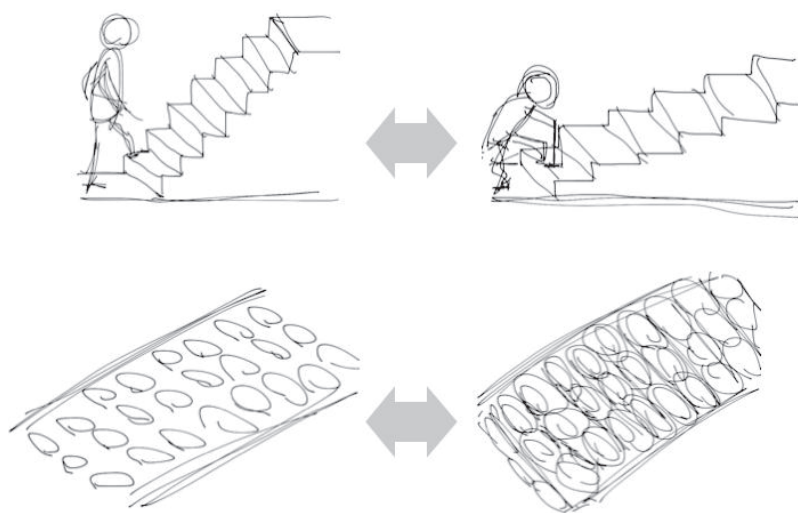

図 5 即時適応性を有した建造物になるロボットのイメージ

に合わせて，自律的にその形状を即時に変化させる．

公園につながる階段の一段ずつの高さを，お年寄りが近 づいてきたら若干低めに再構成するロボットや，ヨーロッ パに見られる石畳を，車椅子が走行する際にはその溝を自 律的に埋めてくれるようなロボットである。

人間は，物理的な世界で生きていて，物理的な環境から， 多くの親しみや安らぎや不安といったものを汲み取ってい る。これらの物理的な環境は，その多くが，地理的な制約 や，物理的な制約から長い時間をかけて培われたものであ る. と同時に, それらの制約は, 人間が生活をしていく上 で，必ずしも都合が良いとは限らない，都合の悪さを楽し んでいる側面も大いにある。しかしながら時と状況に応じ て，それをなんとかしたい場合が少なからずある、ロボッ 卜，特に人間を包み込むレベルでの大きさで環境の一部と なるロボットは，うまく使えばこの不都合を補ってくれる ようになる.

現状でも，建物の機構として，壁の位置を変更できたり， バルコニーを室内に変更するといったことが可能となりつ つある。ここでは，さらに細かい時間的，空間的粒度で， 個々人に合わせて環境が素早くその状況に合わせるロボッ トを考えている.

即時適応性を有した建造物ロボットにとって最も大きな 課題は, 物理環境には, 複数人, 大勢の人々が存在し得る, ということであろう。一人のひとに合わせて階段の段の高 さが低くなったとしても, 別の人にとってはそれが低い長

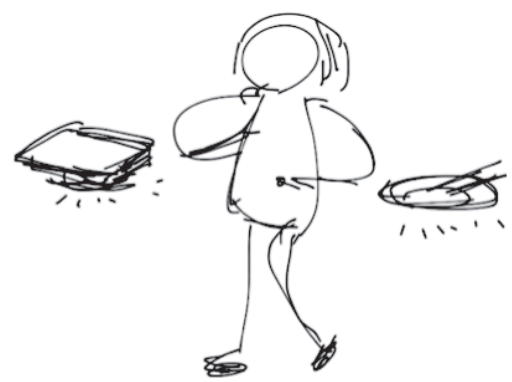

図 6 身の回りを浮遊するロボットのイメージ

い階段になって面倒であろうし，何より自分が上っている階 段の高さが変化したら恐ろしい. 変形中は通行不可などと するのは安直で論外である。 ソフトウェアの世界において は，システムを利用する直接のユーザに加えて，それを見て いる第三者の体験を考えるという, spectator experience design という分野がある [6]. 物理的な環境レベルでのロ ボットでは, これが, クリティカルとなる。

人間は，物理世界は動きや形状に一貫性がある，という 大原則に基づいて, 乳児期から物理世界とのインタラクショ ンを学習する. そしてその学習に基づいて, 雨の歩道を歩 き, 椅子に腰をかけ，箸でモノを食べる，停止中のエスカ レータに足をかけた途端にガクっとなるのも学習の結果で ある.これらが動的にその形状を変え始めるというのが口 ボットである，そういったことに対して人間の脳が成長の 過程において順応できていくのであろうか? 非常に興味 深い.

\section{5 身の回りを浮遊するロボット}

中空にモノを留めることを可能にしてくれるロボットを 考える.

立食のレセプションなどで, 左手でお血を持ち, 右手で飲 み物のグラスを持って，もう 1 本手が欲しいものだとしば しば思う．人間の手が届く腰から胸までの間の高さで, モ ノが中空に静止して，なおかつそれが自分について来てく れれば, 人間の営為のかなりのところが, 非常に楽になる。 直径 $10[\mathrm{~cm}]$ くらいの drone ロボットを考える. 部屋の 中で，それらのロボットがしずしずと浮遊しながら人間の 少し後を着いてくる，ちょっとモノを置きたくなったら，そ の浮遊するロボットの上にモノを置く、打皿やグラスを置 く、そのままそれらのモノが中空に留まる.人間が移動す るとそれらがついてくる.

四六時中そういうホバリングロボットが個々の人間の周 りにいるとする，座っていて，机の上に書類や本を重ねて 置くのではなく，中空に置くことができる，現状は，机の 上, 棚の上, という二次元空間上に積み重ねて置いている 物を，三次元的に置いていくことができる.

このロボットは，ある意味で，人間を重力から部分的に 解放してくれる，と同時に，どこに置いたかを思い出す，と 
いったことがどのくらい認知的に大変になるのか，という 興味が湧く．おそらくISS などではそういうことをしてい るのかなとも思うが, 日常で, 二次元ではなく三次元にモ， を置けるようになったときに，ヒトの暮らしはどのように 変わるか，といったことを考えることは，おそらく 2,300 年のうちには可能になるであろう宇宙空間での居住を考え る際にも役立ちそうだ。

\section{3.おわりに}

外部環境のコンテキストに応じて自律的に物理的な様相 を変化することのできる機構が，人間の身の回り，あるい は自分の中に入り込むとき，どんなことが可能となり得る かを考えてみた，そして，人間がすること，していること に，そのような機構が融合した世界を，〈使うコトの世界〉 の展望として描いてみた。

どれも現状では魔法的かもしれない，まさにSir Arthur C. Clarkeの言どおり, sufficiently advanced technology は magic と見分けが付かないだろう。上に説明した浮遊口 ボットが進化すれば，手を伸ばすと欲しいものが手元に飛 んでくるようになる。まさに魔法使いの杖だ.

課題となるのは, 以下の, 相互に依存する三点と考える. (1) 人間の脳が学んできている物理世界のモデルとの共存： 脳が拠り所としている物理的な世界の機構が，ロボットに よりダイナミックに変容するようになるとき, 人間は対処 できるのか？ 両者に順応できるのか？

（2）ロボットの使い手とそうでない人との共存:物理的な存 在であるロボットは, その使い手でない人にとっても，物 理的に存在する，怖かったり，不安に感じたりすることは 容易に想像できる。普及する世界が広がるまでの過程にお いては，この両者は必ず存在する。

（3）これら二つの課題を踏まえながらヒューマンロボット インタラクションをデザインしていくための手法や技術, ツールやプロセスはどのようにあるべきか？
動きまで含めてプリントされる $4 \mathrm{D}$ プリンティングや, kilobots といった大規模なスウォームロボット群, claytronics を実現するような，プログラムすることのできる材質 (programmable matter) といったものの技術はすでに開 発され始めている，自動運転のクルマが人々が運転するク ルマにすでに混在している，技術の多くは，できてからそ の利用（アプリケーション）を考える，といった風に培わ れてきた，魔法とも言えるような〈使うコトの世界〉の展 望から,〈作るモノの世界〉の技術的課題を考えてみること も面白いのではないだろうか.

謝 辞 本文を執筆するにあたりディスカッションいただ いた山本恭裕氏 (東京大学), Eva-Lotta Sallnaes Pysander 氏（スウェーデン王立工科大学）に感謝する。

\section{参 考 文 献}

[1 ] 中小路久美代, 山本恭裕 : ‘創発のためのソフトウェア’,「知の科学」 シリーズ知性の創発と起源（鈴木宏昭編）。pp.111-131，オーム社, 2006.

[2] 中小路久美代：“ソフトウェアに扔ける 2 つの世界”，情報処理，巻頭 コラム, vol.52, no.12, 2011.

[3] D.A. Schoen: The Reflective Practitioner: How Professionals Think in Action. Basic Books, 1983.

[4] B. Lawson: Design in Mind. Architectural Press, 1994.

[5] B. Buxton: Sketching User Experiences: Getting the Design Right and the Right Design. Morgan Kaufmann, 2007.

[6] S. Reeves, S. Benford, C. O'Malley and M. Fraser: "Designing the Spectator Experience," Proceedings of the SIGCHI Conference on Human Factors in Computing Systems (CHI '05), pp.741-750, 2005.

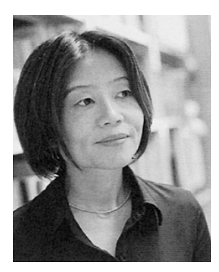

中小路久美代 (Kumiyo Nakakoji)

京都大学学際融合教育研究推進センターデザ イン学ユニット特定教授. 1986 年大阪大学基 礎工学部情報工学科卒業. 株式会社 SRA 入 社. 1993 年米国コロラド大学より Ph.D. 取 得. 奈良先端大学院大学情報学研究科, 東京 大学先端科学技術研究センターを経て 2013 年 より現職. 2006 年コロラド大学より DEAA を受賞. 